\title{
Biology and ecology of sea catfish (Ariidae) of estuarine, lagoon and coastal ecosystems in West Africa
}

\author{
Simier Monique ${ }^{1,{ }^{*}}$, Osse Olaloudé Judicaël Franck ${ }^{2}$, Sadio Oumar ${ }^{3}$, Ecoutin Jean Marc ${ }^{4}$ \\ ${ }^{1}$ MARBEC, Univ Montpellier, CNRS, Ifremer, IRD Sète, France \\ ${ }^{2}$ Institut de Recherche sur les Forêts (IRF) Université du Québec en Abitibi-Témiscamingue Québec, \\ ${ }^{3}$ IRD, Univ Brest, CNRS, Ifremer, LEMAR BP Dakar, Sénégal \\ 4 IRD, Univ Brest, CNRS, Ifremer, LEMAR Plouzané, France \\ *Corresponding author : Monique Simier, email address : $\underline{\text { monique.simier@ird.fr }}$
} Canada

\begin{abstract}
:
The family Ariidae, sea catfish of the order Siluriformes, is widely distributed throughout the world, particularly in tropical and sub-tropical areas. The three species of Ariidae found on the coasts and estuaries of West Africa are the smoothmouth catfish Carlarius heudelotii (Valenciennes 1840), the roughhead catfish Carlarius latiscutatus (Günther 1864) and the Guinean sea catfish Carlarius parkii (Günther 1864). They have been increasingly exploited by artisanal and industrial coastal fisheries in recent decades, but there is still little information available on their ecology and biology. The aim of this study was to deepen our knowledge of these three West African Ariidae species, based on a dataset collected between 1980 and 2013 during experimental fishing programmes. They were carried out in Mauritania in the Banc d'Arguin National Park (PNBA), in Senegal in the Sine Saloum estuary including the Bamboung Marine Protected Area (MPA), in The Gambia in the Gambia estuary, in Guinea-Bissau in the Urok Islands MPA in the Bijagos archipelago, in Guinea in the Fatala estuary and Dangara inlet, and in Côte d'Ivoire in the Ebrié Lagoon. C. latiscutatus accounted for $65 \%$, C. parkii for $29 \%$ and C. heudelotii for $6 \%$ of total number of Ariidae sampled. C. latiscutatus was abundant in the Sine Saloum and Gambia estuaries as well as in Guinea and Guinea-Bissau and was the only species present in the Ebrié Lagoon. C. parkii was in the majority in Mauritania. The three species were recorded in a salinity range of 0 to 50 , a temperature range of 19 to $34{ }^{\circ} \mathrm{C}$, in areas 1.7 to $15 \mathrm{~m}$ depth, and transparency ranging from 0.1 to $4 \mathrm{~m}$ (Secchi disk depth). C. heudelotii was present in less saline ( 25 vs. $32-34)$, less warm (27 vs. $29{ }^{\circ} \mathrm{C}$ ) and less transparent ( $0.8 \mathrm{~m}$ vs. $1.6 \mathrm{~m})$ waters than the two other species. The maximum sizes $(453 \mathrm{~mm}, 614 \mathrm{~mm}$, and $525 \mathrm{~mm}$, for respectively, C. heudelotii, C. latiscutatus and C. parkii) were comparable to those recorded at sea. Length-weight relationships calculated for each species showed b coefficients greater than 3. Sex ratios were always in favour of females. The number of mature individuals and their smallest size at maturity were calculated per species, sex, and study area. A size of 27 to $28 \mathrm{~cm}$ at first maturity was estimated for females of $\mathrm{C}$. latiscutatus. A few dozen records made it possible to describe fecundity and cases of oral incubation by females. The diet of the three species was composed of crustaceans, fish and mollusks, confirming their classification as generalist predators. Thanks to their high environmental tolerance, these sea catfish populations are able to occupy both the continental shelf and adjacent estuaries throughout their life cycle, with the exception of spawning, which generally takes place at sea.
\end{abstract}


Keywords : Ariidae, euryhalinity, marine catfish, tropical estuary, West Africa 


\section{Introduction}

The family Ariidae, sea catfish of the order Siluriformes, is widely distributed throughout the world, particularly in tropical and sub-tropical areas (Marceniuk and Menezes, 2007). They are of marine origin, but many species enter estuaries, and some are confined to freshwater (Vreven and De Vos, 2007). In a review of diversity and conservation of Malaysian fishes, Ariidae have been reported in freshwater, marine and estuarine habitats (Chong et al., 2010). In Papua New Guinea, they are an important component of the native freshwater ichthyofauna (Coates, 1991). Ariidae species are among the most abundant fishes in the Gulf of Mexico coastal zone (Yañez-Arancibia and Lara-Dominguez, 1988). They are predominant in density and biomass in the main channel of the Goiana estuary in north-east Brazil (Dantas et al., 2010), and they are listed among the most ubiquitous families in a comparison between the fish assemblages of the Embley (north Australia) and Caeté (north Brazil) estuaries (Barletta and Blaber, 2007).

The Ariidae are characterised by three pairs of barbels, two closely spaced nostrils on either side of the head, short dorsal and anal fins, a forked caudal fin, and the presence of an adipose fin; their head is covered with bony plates (Daget, 1992; Vreven and De Vos, 2007). The West African species originally belonged to the genus Arius (Burgess, 1989; Daget, 1992; Fowler, 1936; Taylor, 1986, 1990) and were recently classified in a new genus, Carlarius, by Marceniuk (2003) who recognised them as a monophyletic lineage (Fricke et al., 2020). The genus Carlarius differs from the genus Arius in that the lateral line does not bifurcate in the caudal region, reaching the upper lobe of the caudal fin and that the epi-occipital bone is exposed on the dorsal part of the skull (Marceniuk and Menezes, 2007).

The three species of Ariidae recorded on the coasts of West Africa (Acero and Betancur, 2016; Daget, 1992) are the smoothmouth catfish Carlarius heudelotii (Valenciennes 1840), the rough-head catfish Carlarius latiscutatus (Günther 1864) and the Guinean sea catfish 
Carlarius parkii (Günther 1864). They occur mainly in coastal waters on muddy bottoms and regularly enter the brackish waters of estuaries and coastal lagoons (Conand et al., 1995). A fourth species present in West Africa, the giant sea catfish Carlarius gigas (Boulanger 1911), is strictly confined to freshwater and has never been caught at sea (Daget, 1992).

In West African coastal environments, Ariidae are an important component of the demersal populations. They belong to the coastal Sciaenid community (Domain, 1980; Domain et al., 1999; Longhurst, 1969), characteristic of soft bottoms from the coast to a depth of 20-30 m and of warm, potentially desalinated waters near estuaries. They are Marine-Estuarine species in the sense of Albaret (1999), i.e., highly euryhaline marine species that are abundant in estuarine and lagoon environments. Their distribution in these ecosystems is relatively widespread and permanent throughout the year; however, their reproduction takes place at sea. In the ecological guild proposed by Whitfield (2005) for fishes of Central and West African estuaries, C. latiscutatus and $C$. parkii belong to the category of marine migrants which generally reproduce at sea and whose juveniles and/or adults live in estuaries, while C. heudelotii is a marine straggler, of which only a small proportion of the population enters the estuary, generally near the mouth.

A number of recent works have highlighted the increasing importance of coastal Ariidae in the marine and estuarine fisheries of several West African countries. In Mauritania, all three species are fished in the EEZ, most notably C. heudelotii, which over the period 2000-2006 accounted for an average 3,378 t/year or $4.1 \%$ of the Mauritanian artisanal fisheries catch (Gascuel et al., 2006). Particularly in the Banc d'Arguin National Park (PNBA), the landings of Ariidae have been increasing from $170 \mathrm{t}$ in 2001 to $450 \mathrm{t}$ in 2007, peaking at $674 \mathrm{t}$ in 2005 (Correia et al., 2020). In Senegal, Ariidae are one of the main coastal demersal resources, with a high export value, and the industrial Ariidae fishery, which started in 1977 with about 1,000 t/year, reached 8,892 t/year in 2014 (Diop et al., 2017). In a recent study on the long- 
term impact of fishing on Senegalese coastal demersal resources, which combined industrial and artisanal fishing CPUEs since the early 1970s and scientific trawl sampling surveys from 1986 to 2008, Ariidae came third in scientific fisheries and, of the 10 main demersal stocks studied, dominated by weight with $20 \%$ of CPUEs on average (Ba et al., 2018). However, according to these authors, the trend has been towards a jagged decline since the 1980s and Ariidae are currently considered overexploited. On the Petite Côte of Senegal, Ariidae were among the main species fished between 2004 and 2013, mainly with set nets and longlines (Ndour et al., 2016). In the Casamance estuary (Senegal), a study of by-catches of fixed shrimp gillnets in 2016 showed that C. latiscutatus was present in 23\% of landings but accounted for only $0.44 \%$ of total catches, with individuals caught being either discarded or kept, depending on their size, and often smoked (Diadhiou et al., 2018). In the Gambia estuary, in 2001-2002, Ariidae were one of the two taxa representing half of fish landings and accounted for 20\% of catches by artisanal fisheries (Laë et al., 2004). From 2005 onwards, their landings increased significantly, as a major by-catch of the bottom gillnet sole fishery in the Gambia estuary, and the stock assessment carried out in 2013 to estimate fishing mortality of C. latiscutatus and C. parkii led to recommendations to close the fishery from May to October, during their spawning period, and to increase mesh size for gillnets (Castro et al., 2013). In Guinea-Bissau, a study carried out in the Bijagos archipelago between 2008 and 2010 showed that marine catfish accounted for $13 \%$ of the catches obtained by small-scale fisheries (Cross, 2015). In Guinea, the continental shelf is home to the largest Sciaenid community in the Gulf of Guinea and has enabled development of an important artisanal fishery sector but, having been competitively exploited by industrial trawler fishing, it showed signs of overexploitation in 1999 (Domain et al., 1999). As a result of increasing fishing pressure from 1985 to 2012, Guinea's demersal assemblages thus suffered an overall decline and the large species (including Ariidae), which dominated Guinean artisanal and industrial 
fisheries until the early 2000s, were gradually replaced by smaller species of lower commercial value (Camara et al., 2016).

Despite their importance in West African coastal fisheries, there is still little information available on the ecology and biology of these three Ariidae species (Correia et al., 2020). Biometric size-age relationships were proposed for Guinean marine catfish by Conand et al. (1995), who highlighted their slow growth and therefore their high vulnerability to exploitation. According to these authors, the Ariidae would reach 40 to $42 \mathrm{~cm}$ at the age of 6 and the $80 \mathrm{~cm}$ individuals quite often caught by small-scale fisheries would be between 20 and 30 years old. In a recent study on the reproductive biology of Ariidae from two coastal bays of Guinea, Koivogui et al. (2020) concluded that they had only one breeding season, during which coastal fisheries should be restricted to preserve the ability of broodstock renewal. Concerning estuarine areas, some aspects of the biology of Ariidae among other fish species were studied in the Sine Saloum estuary (Ecoutin and Albaret, 2003; Faye et al., 2012; Ndiaye et al., 2015; Panfili et al., 2006) and in the Gambia estuary (Ecoutin et al., 2005a). Diop et al. (2017) compared the reproductive traits of C. latiscutatus inside and outside the Bamboung MPA (Sine Saloum, Senegal), and confirmed that the breeding season for this species lasts from March to July. Finally, the reproductive ecology and growth of C. latiscutatus and C. parkii in the PNBA were investigated by Correia et al. (2020), who proposed a short-term fishing closure in May and June, during their spawning period.

The aim of the present work is to consolidate our knowledge of the ecology and biology of the three West African species of Ariidae using a large dataset from experimental fishing programmes that covered several estuarine, lagoon and coastal ecosystems from Mauritania to Côte d'Ivoire between 1980 and 2013. We will (1) compare the distribution of abundance of the three species in these ecosystems, in order to highlight their coastal or estuarine affinities, (2) propose environmental trends for each species in terms of salinity, temperature, depth and 
water transparency, in order to characterise their degree of tolerance to the variations of the water physical-chemical parameters, (3) describe the size structures for the three species and propose length-weight relationships and condition factors, (4) compute indicators of the reproductive status (sex ratio, size of the smallest mature individual, size at first maturity) of these species and (5) investigate the hypothesis that these catfishes are generalist predators using observations of their stomach content.

\section{Materials and Methods}

\section{Data Collection}

This work is based on a dataset that is part of the PPEAO information system (www.ppeao.ird.fr) on fish assemblages and artisanal fisheries in West African estuaries, lagoons, and reservoirs. The data were collected between 1980 and 2013 during experimental fishing programmes and surveys of artisanal fisheries. They concern the ecology and biology of fish species in these ecosystems and their exploitation by artisanal fishing. The data used for the present study came only from the experimental fishing programmes archived in PPEAO (Simier et al., 2019).

\section{Study area}

From north to south (Figure 1), the data were collected in Mauritania in the Banc d'Arguin National Park (PNBA - Sadio, 2015), in Senegal in the Sine Saloum estuary (Diouf, 1996; Ecoutin et al., 2010) including the Bamboung Marine Protected Area (Ecoutin et al., 2014; Sadio et al., 2015), in The Gambia in the Gambia estuary (Albaret et al., 2004), in GuineaBissau in the Urok Islands Marine Protected Area located in the Bijagos archipelago (Sadio, 2015), in Guinea in the Fatala estuary and Dangara inlet (Baran, 1995), and finally in Côte d'Ivoire in the Ebrié Lagoon (Albaret, 1994).

\section{Sampling methodology}


A purse seine net (length $250 \mathrm{~m}$, height $20 \mathrm{~m}$, mesh size $14 \mathrm{~mm}$ ) was used to sample fish populations in all the ecosystems studied, with the exception of the Urok Islands MPA in Guinea-Bissau, where batteries of surface and bottom gillnets of different mesh sizes $(14,25$, 36, 50, 60 and $80 \mathrm{~mm}$ ) were set overnight. The fish caught were identified by species and their abundance was quantified based on their number and weight. Individual measurements of fork length (to the nearest $\mathrm{mm}$ ) and weight (to the nearest g), identification of the sex and the stage of maturity, as well as identification of stomach contents were also carried out. The main physical-chemical parameters of the aquatic environment were measured on each fish sampling occasion: depth of the bottom at the sampling location with a hand-sounder, water transparency with a Secchi disc of $30 \mathrm{~cm}$ in diameter, salinity with a refractometer and temperature of the surface water with a thermometer.

\section{Data processing}

The overall geographical distribution of the species is described using 390 fishing operations containing Ariidae. The proportion of fishing operations containing Ariidae and their ecological preferences were determined on the basis of 1,453 fishing operations (whether these contained Ariidae or not) belonging to the standardised sampling protocol representative of an ecosystem as a whole and in all seasons. The search for environmental preferences was limited to C. latiscutatus and C. parkii because too few data were available for C. heudelotii. A total number of 4,775 individuals of the family Ariidae were caught. Of these, 2,811 were the subject of biological records, at least the measurement of individual fork length (in mm). When more than 50 individuals of the same species were caught in the same fishing operation, random sub-sampling was carried out, and the size structures were extrapolated to all the individuals. The population structure was described by size frequency distributions and mean and maximum length in all three species. Of the 2,811 individuals measured, 1,866 were also weighed individually allowing the calculation of length-weight relationships, 
globally and for each species. Linear regressions of $\log (\mathrm{W})$ vs. $\log (\mathrm{FL})$, where $\mathrm{W}$ is the total weight in $\mathrm{g}$ and FL is the fork length in $\mathrm{mm}$, were calculated to obtain the length-weight relationship of the form $\mathrm{W}=\mathrm{K}^{*} \mathrm{FL}^{\mathrm{b}}$ (Froese, 2006) where $\log (\mathrm{K})$ is the intercept and $\mathrm{b}$ is the slope of the log-log regression. Individuals considered as outliers in a first step which involved all the data, were discarded in a second regression to improve the quality of the fit. Out of 2,140 sexed individuals, sex ratios were calculated and evaluation of the stage of sexual maturity according to Albaret and Legendre (1985) made it possible to determine the number of mature individuals and the size of the smallest mature individual per species, per sex and per country. The size at first maturity (fork length at which 50\% of the individuals are mature or FL50) could only be estimated for females of C. latiscutatus in the Sine Saloum and Gambia estuaries. This was done by logistic regression, after grouping the individuals into $1 \mathrm{~cm}$ size classes and calculating the percentage of mature individuals in each class. To complete the description of reproduction, 22 occasional records of fecundity (number of eggs in the gonads of mature females) and 27 records of oral incubation (presence of eggs or embryos in the mouth) were also considered. Finally, the feeding behaviour of the three species is described on the basis of 290 records of stomach contents. Statistical analyses and graphs were carried out with R software (R Core Team, 2020).

\section{Ethical statement}

The scientist in charge of data collection and fish manipulation holded the "University Diploma in Animal Experimentation, Level II Accreditation n I-51UFRReims-S2-09 from the University of Reims Champagne-Ardennes” and the "Animal Experimentation School Diploma - Design and implementation of experimental procedures at the Laboratory of Animal Physiopathology and Functional Pharmacology at ONIRIS - Ecole Nationale Vétérinaire, Agroalimentaire et de l'Alimentation Nantes Atlantique”, which ensures that animal welfare was respected during the faunal surveys. No harsh practices or chemicals were 
used to immobilise or kill the fish before handling. Measurement, weighing and observation of gonads and stomach contents were done after the fish were dead. No specimens were processed alive.

\section{Results}

\section{Spatial distribution}

Ariidae were recorded in all the ecosystems sampled in West Africa, i.e., between $22^{\circ} 07 \mathrm{~N}$ (PNBA in Mauritania) and $5^{\circ} 18 \mathrm{~N}$ (Ebrié Lagoon in Côte d'Ivoire). Among the 4,775 individuals collected, 6\% were C. heudelotii, 65\% C. latiscutatus and 29\% C. parkii. The proportion of purse seines containing at least one Ariidae of any species was $32 \%$ in Mauritania, 22\% in Senegal and Guinea, 40\% in The Gambia. It reached 97\% in gillnet batteries in Guinea-Bissau. Table 1 lists the distribution of the three Ariidae species per ecosystem in terms of number of occurrences, numbers, and biomass. In the Banc d'Arguin National Park, the most abundant species was C. parkii (76\% of Ariidae abundance), followed by C. heudelotii (23\%) while C. latiscutatus was almost absent. In the Sine Saloum estuary (including Bamboung MPA), the Gambia estuary and the Urok Islands MPA, C. latiscutatus dominated (from $60 \%$ of Ariidae abundance in the Sine Saloum to $75 \%$ in the Urok Islands MPA), followed by C. parkii. C. heudelotii was rarely recorded (maximum $8.4 \%$ of Ariidae abundance in the Gambia estuary), if at all in the Urok Islands MPA. In Guinea, C. parkii was rarely present, and C. latiscutatus accounted for $60 \%$ of Ariidae abundance in the Fatala estuary, compared to only $14 \%$ in the Dangara inlet where $C$. heudelotii was dominant. In the Ebrié Lagoon, Ariidae were very rare, only six occurrences of C. latiscutatus were recorded and none for the other two species, so this ecosystem was subsequently disregarded.

\section{Environmental trends}


Salinity where Ariidae were recorded ranged from 2.5 to 43 with a median value of 25 for C. heudelotii, from 0 to 50 with a median of 31.9 for C. latiscutatus, and from 7 to 50 with a median of 34 for $\mathrm{C}$. parkii (Figure 2A). The temperature range was $20.7{ }^{\circ} \mathrm{C}$ to $32{ }^{\circ} \mathrm{C}$ with a median of $27^{\circ} \mathrm{C}$ for $\mathrm{C}$. heudelotii, $22.5^{\circ} \mathrm{C}$ to $34^{\circ} \mathrm{C}$ with a median of $29^{\circ} \mathrm{C}$ for $\mathrm{C}$. latiscutatus and $19.3^{\circ} \mathrm{C}$ to $34^{\circ} \mathrm{C}$ with a median of $28.7^{\circ} \mathrm{C}$ for $\mathrm{C}$. parkii (Figure 2B). The bottom depth at the location of the fishing sites varied between $1.7 \mathrm{~m}$ and $15 \mathrm{~m}$, with a median of around $6 \mathrm{~m}$ (Figure 2C). Ariidae were present in a range of transparency from $0.1 \mathrm{~m}$ to $4 \mathrm{~m}$ (Secchi disk depth), with a median value of $0.8 \mathrm{~m}$ for $C$. heudelotii versus $1.6 \mathrm{~m}$ for the other two species (Figure 2D). In the Gambia estuary, which was sampled over a distance of $220 \mathrm{~km}$, C. heudelotii, C. latiscutatus and C. parkii were occasionally recorded up to $117 \mathrm{~km}, 140 \mathrm{~km}$ and $173 \mathrm{~km}$ from the mouth, respectively. In the Sine Saloum estuary, all three species were present up to $30 \mathrm{~km}$ from the mouth, but never in the following $110 \mathrm{~km}$ upstream.

The range of salinity with the highest occurrence of C. latiscutatus was 10 to 30, more particularly 15 to 20, where the species was present in $40 \%$ of fishing operations. C. parkii was preferentially found between 15 and 20 and between 30 and 35 (20 to 25\% of operations). Neither species was recorded at a salinity higher than 50 , while fishing operations occurred up to salinities of 134 in the inverse estuary of the Sine Saloum in Senegal. In terms of water surface temperature, the preferred range of $C$. latiscutatus was between 24 and $32{ }^{\circ} \mathrm{C}$, where it was present in 20 to $30 \%$ of the fishing operations. Although samplings were made at temperatures as low as $16{ }^{\circ} \mathrm{C}, \mathrm{C}$. latiscutatus was never found below $22{ }^{\circ} \mathrm{C}$, but was found at the highest temperatures encountered $\left(32^{\circ} \mathrm{C}\right)$. C. parkii was recorded from $19{ }^{\circ} \mathrm{C}$ and its preferential range was between 22 and $26^{\circ} \mathrm{C}$ and between 30 and $32{ }^{\circ} \mathrm{C}$, where it was present in $17 \%$ of the fishing operations. The depth range where C. latiscutatus and C. parkii were found in the highest occurrence was between 3 and $9 \mathrm{~m}$ (25 to 32\% and 15 to $20 \%$ of the fishing operations respectively). The two species were only recorded at depths down to $15 \mathrm{~m}$, 
although samplings were conducted down to a depth of $20 \mathrm{~m}$. In terms of transparency, C. latiscutatus was frequent between 0 and $2.5 \mathrm{~m}$ (more than $20 \%$ of operations) and the maximum occurrence was found between 0.5 and $1.0 \mathrm{~m}$ (32\% of operations). The transparency preference for $C$. parkii was between $0.5 \mathrm{~m}$ and $1.5 \mathrm{~m}$ where the species was present in $20 \%$ of the fishing operations. The two species were never recorded when the transparency was higher than $4 \mathrm{~m}$.

\section{Size structure}

Of the 2,811 individuals subjected to biological records, $8 \%$ were C. heudelotii, $60 \%$ C. latiscutatus and 32\% C. parkii. In C. heudelotii (279 individuals), fork length ranged between 84 and $453 \mathrm{~mm}$ with an average of $193 \mathrm{~mm}$ (Table 2) and the main mode was between 120 and $180 \mathrm{~mm}$, with a second, less marked mode between 220 and $280 \mathrm{~mm}$ (Figure 3). The length of the most abundant species, C. latiscutatus (3,136 individuals after extrapolation) ranged between 53 and $614 \mathrm{~mm}$, with an average length of $302 \mathrm{~mm}$ and a wellmarked mode between 280 and $340 \mathrm{~mm}$. Finally, the size distribution of 1,401 individuals of C. parkii, whose lengths ranged between 72 and $525 \mathrm{~mm}$ with an average of $275 \mathrm{~mm}$, was more widespread with no obvious mode. The smallest individuals (50 to $80 \mathrm{~mm}$ ) were often found in the mouths of large individuals.

The maximum sizes of all three species were recorded in Senegal, i.e., $453 \mathrm{~mm}$ for C. heudelotii, $614 \mathrm{~mm}$ for C. latiscutatus and $525 \mathrm{~mm}$ for C. parkii (Table 3). C. heudelotii rarely exceeded $400 \mathrm{~mm}$ : apart from the maximum size, only one individual of $410 \mathrm{~mm}$ was caught in The Gambia. In C. latiscutatus, sizes of above $500 \mathrm{~mm}$ were measured 18 times in Senegal and Guinea-Bissau. In C. parkii, sizes larger than $500 \mathrm{~mm}$ were rare: apart from two individuals measuring $525 \mathrm{~mm}$ and $500 \mathrm{~mm}$ in Senegal, only one individual of $508 \mathrm{~mm}$ was recorded in Mauritania. 


\section{Length-weight relationships and condition factor}

Despite the limited number of C. heudelotii (230 individuals measured but only 24 of them weighed), a good adjustment was obtained as for the other species ( $\mathrm{r}=0.99)$. The allometry coefficient b was higher than 3 in all three species. The condition coefficient $\mathrm{K}$ (expressed in $10^{-5}$ ) ranged from 0.417 for C. latiscutatus to 0.714 for $C$. heudelotii, via 0.627 for $C$. parkii (Table 4).

\section{Reproduction}

The distribution per species and sex showed that the sex ratio was always in favour of females whatever the species: 1.2 in C. heudelotii, 2.04 in C. latiscutatus, and 1.5 in C. parkii (Table 5). The proportion of immature individuals was much higher in C. heudelotii than in the other two species. In the smallest size classes (up to $24 \mathrm{~cm}$ for C. latiscutatus and $21 \mathrm{~cm}$ for $C$. parkii), the sex ratio was generally balanced, with the proportion of females increasing considerably above these sizes.

Of the 689 males, only 90 (13\%) reached a stage of maturity corresponding to the beginning of sexual maturation (stage 3 on the scale of Albaret and Legendre, 1985). Most were $C$. parkii or C. latiscutatus (only 2 C. heudelotii). Of these, 37 individuals had reached maturity (stage 4), including 27 C. parkii and 10 C. latiscutatus caught in the Sine Saloum estuary. The smallest maturing male, a C. parkii caught in the Sine Saloum estuary, measured $239 \mathrm{~mm}$ (Table 6). In C. latiscutatus, the smallest maturing male was recorded in Guinea and measured $245 \mathrm{~mm}$. In C. heudelotii, only two males were recorded at stage 3 or 4, both in Guinea, the smallest one measured $248 \mathrm{~mm}$. Of the 1,245 females, 399 (32\%) had begun sexual maturation. Of these, 236 were maturing (stage 3), 88 were mature (stage 4), 11 were in the spawning phase (stage 5) and 64 were at spent stage (stage 6). As with the males, 
C. heudelotii was very rarely recorded at maturity (only 7 females at stage 3 or above). The smallest maturing $C$. heudelotii female was $280 \mathrm{~mm}$ long in Mauritania, the smallest maturing C. latiscutatus female was $225 \mathrm{~mm}$ long in The Gambia and the smallest maturing C. parkii female was $190 \mathrm{~mm}$ long in Senegal (Table 6).

There were only sufficient female C. latiscutatus individuals at the beginning of the sexual maturity process (stage $\geq 3$ ) to allow the calculation of size at first maturity (FL50). In the Sine Saloum estuary in Senegal, FL50 was estimated at $28.12 \pm 1.01 \mathrm{~cm}$, for a sample of 214 individuals of which 121 were mature. In The Gambia, FL50 was estimated at $27.79 \pm$ $0.54 \mathrm{~cm}$ for 66 individuals of which 26 were mature.

Fecundity was occasionally evaluated for female C. latiscutatus $(\mathrm{n}=6)$ and C. parkii $(\mathrm{n}=16)$ in the Sine Saloum and Gambia estuaries, from March to June, at the reproduction season. For C. latiscutatus, 13-20 eggs in the gonads were reported, i.e., an average of $16.2 \pm 2.8$ eggs per female. For C. parkii, fecundity ranged between 13 and 49 eggs with an average of $26.3 \pm 10$ eggs per female. In addition, cases of oral incubation of eggs or embryos by C. latiscutatus $(\mathrm{n}=8)$, C. parkii $(\mathrm{n}=19)$ and C. heudelotii $(\mathrm{n}=1)$ were recorded, at the same season, in the Sine Saloum and the Gambia estuaries. These were always females at spent stage, or sometimes in the spawning phase, varying in size from 250 to $495 \mathrm{~mm}$. They carried in their mouths either eggs, embryos or young individuals less than $70 \mathrm{~mm}$ in size, sometimes with their yolk sac. For $C$. parkii $(n=6)$ the number of eggs in the mouth ranged between 12 and $63(30 \pm 17.8)$.

\section{Feeding behaviour}

Stomach contents were identified in 290 individuals (Table 7). Among these, the great majority were C. latiscutatus (233 individuals), 55 C. parkii and only two C. heudelotii. The majority of these records were made in Guinea-Bissau and Senegal. 
In $79 \%$ of the cases, only one type of content was identified; in $18 \%$ of cases there were two, and in only nine individuals, three to five different contents were identified in the same stomach. A total of 365 items were recorded. The most frequent was crab $(37 \%$ of occurrences) such as Callinectes sp. and Uca sp., followed by fish (23\%), including pelagic fish such as Sardinella maderensis and Ethmalosa fimbriata, mollusks (13\%), mainly bivalves, and shrimps (5\%). In C. latiscutatus and C. parkii, the occurrence of fish was similar (22-24\% of stomachs), whereas crabs were more frequently recorded in C. latiscutatus (40\%) than in C. parkii (22\%). Conversely, bivalves were more frequent in C. parkii (9\%) than in C. latiscutatus (3\%).

\section{Discussion}

\section{Spatial distribution}

This study highlighted the significant presence of the three coastal Ariidae species known in West Africa in several estuarine and very coastal areas from Mauritania to Côte d'Ivoire (i.e., between $22^{\circ} \mathrm{N}$ and $5^{\circ} \mathrm{N}$ ). This is consistent with the distribution of these species along the West African coasts according to Acero and Betancur (2016), i.e., C. heudelotii from Cabo Blanco (Mauritania) to Gabon and potentially Angola, C. latiscutatus from northern Senegal to Namibia and C. parkii from Cabo Blanco (Mauritania) to Angola.

C. heudelotii was recorded in most of the areas studied here (except the Urok Islands and the Ebrié Lagoon) but generally in small numbers. It was abundant only in the Dangara inlet in Guinea and in the Banc d'Arguin National Park in Mauritania, both widely connected to the sea and without freshwater inputs. This is in adequacy with the classification of $C$. heudelotii by Whitfield (2005) as a marine straggler, category of which only a small proportion of the population enters the estuaries, generally near the mouth. C. heudelotii, commonly caught around 12-14 m on the Guinean continental shelf, is part of the coastal Sciaenid community, 
grouping shallow-water species characteristic of sandy-muddy bottoms close to the coast, and rarely recorded at depths of more than $30 \mathrm{~m}$ (Conand et al., 1995; Domain et al., 1999). Thus, in the 1970s and 1980s, C. heudelotii was the main coastal species caught by the Senegalese artisanal fishing trawlers (Caverivière and Thiam, 1993). The two other species, C. latiscutatus and C. parkii, in the majority in the present study, are marine migrants according to Whitfield (2005), i.e. species which generally reproduce at sea and whose juveniles and/or adults live in estuaries. C. latiscutatus accounted for two-thirds of the total number of Ariidae in the estuaries of Sine Saloum and Gambia, as well as in the Urok Islands. C. latiscutatus, caught at sea in depths of between 8 and $14 \mathrm{~m}$, was considered by Domain et al. (1999) to be a more coastal species than C. heudelotii. C. parkii accounted for almost one third of the total number of Ariidae in the present study. According to Domain et al. (1999), C. parkii, not abundant on the Guinean continental shelf, is characteristic of the estuarine Sciaenid community. In the present study, it made up three quarters of the abundances of Ariidae in the Banc d'Arguin National Park in Mauritania. C. parkii has occasionally been recorded on the Moroccan coast (Daget, 1986) and in the Mediterranean Sea (Golani and BenTuvia, 1986; Golani and Sonin, 1996), where it was classified by CIESM (2002) as an 'alien' species (Kaimuddin et al., 2016). Its dominance among the Ariidae in the Banc d'Arguin National Park tends to confirm that it is the most northerly of the three species.

Along the coast from Mauritania to Guinea, the Ariidae species account for a large proportion of the Sciaenid community (Caverivière et al., 1988; Domain, 1980; Domain et al., 1999). The wideness of the Senegalese-Mauritanian and Guinean shelves, $40 \mathrm{~nm}$ in front of the PNBA to 68 nm off Guinea-Bissau (Domain, 1977; Domain and Richer de Forges, 1985) could be a factor favouring the abundance of these very coastal demersal species living on muddy and sandy-muddy bottoms at shallow depths. Their significant presence reported in the present study in the estuaries of Senegal, Gambia, Guinea and the Bijagos archipelago 
suggests that these ecosystems are a natural part of the habitat of coastal populations of Ariidae. In the Gambia estuary, the presence of Ariidae up to $173 \mathrm{~km}$ from the mouth attests to their wide use of estuaries, in agreement with data from small-scale fisheries reporting the frequent landing of Ariidae $187 \mathrm{~km}$ from the mouth of the Gambia estuary (Laë et al., 2004). In the Casamance estuary, C. latiscutatus and C. parkii were recorded in landings up to $170 \mathrm{~km}$ and $93 \mathrm{~km}$ from the mouth, respectively (Kantoussan et al., 2012). In the Ebrié Lagoon (Côte d'Ivoire), however, Ariidae were very rare, the only species occasionally encountered being C. latiscutatus. This could be related to their limited abundance along the coast in Côte d'Ivoire, where they are not among the main demersal species (Caverivière, 1982; Caverivière, 1993). The narrowness of the Ivorian continental shelf, only $10 \mathrm{~nm}$ off Abidjan (Martin, 1973), could be an unfavourable factor for the settlement of Ariidae populations off Côte d'Ivoire and therefore in the Ebrié Lagoon. Indeed, further south, opposite the Congo, where the continental shelf widens, Ariidae are among the dominant species of coastal settlement (Fontana, 1981). Another hypothesis concerning the limited abundance of Ariidae in the Ebrié Lagoon could be the competition with estuarine catfish of freshwater origin belonging to the family Claroteidae (Chrysichthys maurus, Chrysichthys nigrodigitatus and Chrysichthys auratus), which are more regularly encountered and may occupy a similar ecological niche (Albaret, 1994; Ecoutin et al., 2005b).

In Mauritania, Senegal, The Gambia, and Guinea, 22 to $40 \%$ of fishing operations caught at least one Ariidae. This family appears to be very ubiquitous in West African estuaries but, in terms of numbers and biomass, it represents a small part of the fish assemblages (Baran, 1995). In the Banc d'Arguin in Mauritania, the Ariidae accounted for a very low percentage of the total numbers and biomass, with the exception of $C$. parkii representing $8 \%$ of the biomass and $3.7 \%$ within the PNBA (Sadio, 2015). In the Sine Saloum estuary, the fish communities were dominated by the small pelagic species Sardinella maderensis, Ethmalosa 
fimbriata and Ilisha africana and the Ariidae were not abundant (Simier et al., 2004). In the Bamboung MPA, however, the biomass of C. latiscutatus and C. parkii increased from year to year from the implementation of the fishing ban in 2003 to 2007: 11 to $572 \mathrm{~kg}$ and 9 to 195 kg respectively (Ecoutin et al., 2014). In the same way, when comparing the fish assemblages in the Bamboung MPA to an unprotected neighbouring site, Sadio et al. (2015) showed that C. latiscutatus represented $24 \%$ of the biomass in the MPA vs. only $0.5 \%$ in the unprotected site. In the Gambia estuary, the fish communities were largely dominated by the Sciaenidae Pseudotolithus elongatus, followed by the Clupeidae Ethmalosa fimbriata, Ilisha africana and Sardinella maderensis, while the three Ariidae species represented only $3.3 \%$ of the biomass and $1.3 \%$ of the numbers (Albaret et al., 2004). In the Fatala estuary, the Ariidae accounted for less than $1 \%$ of the numbers and biomass, except $C$. parkii with $2.3 \%$ of the total biomass (Baran, 1995). All these fishing operations were carried out using a purse seine net, which is considered as more effective in sampling pelagic fish than demersal fish (Paugy and Lévêque, 1999). This purse seine net, however, was the same for all experimental fishing programmes, allowing reproducible sampling of fish assemblages, and was not very selective in its design (length $250 \mathrm{~m}$, height $20 \mathrm{~m}$, mesh size $14 \mathrm{~mm}$ ) and the way it was used without any surface search for schools of fish (Albaret and Legendre, 1985; Albaret et al., 2004). In addition, the water depth never exceeded $15 \mathrm{~m}$, so the entire water column was sampled. In contrast, in the Urok Islands MPA in Guinea-Bissau, sampled using gillnets, C. latiscutatus and C. parkii, caught in almost all fishing operations, were also in the majority among the fish assemblages: respectively $30 \%$ and $10 \%$ of numbers and $34 \%$ and $9 \%$ of biomass (Sadio, 2015). Gillnets are indeed very selective for Ariidae which get easily meshed or hung due to the long erectile spines of their dorsal and pectoral fins.

\section{Environmental trends}


All three species were present in a wide range of salinity conditions, from freshwater to salty water, but never above 50 . These results confirm, with a greater number of individuals, the outcomes of Panfili et al. (2006) for a sampling of the Sine Saloum and Gambia estuaries included in the present dataset. Ariidae, despite their euryhalinity, are not able to withstand extreme values of salinity such as those in the upstream part of the Sine Saloum estuary. The Sine Saloum has been affected by climate change in the decades before the 1990s, with a long period of drought resulting in a reversal of the salinity gradient and very high salinities $(>100)$ in the upper estuary (Ecoutin et al., 2010). The range of water temperatures where Ariidae were recorded was also wide, up to $34{ }^{\circ} \mathrm{C}$, but never below $19{ }^{\circ} \mathrm{C}$. All three species were caught in maximum water depths of $15 \mathrm{~m}$ and in a range of transparency from $0.1 \mathrm{~m}$ to $4 \mathrm{~m}$. C. latiscutatus and C. parkii were recorded in very similar environmental conditions, while C. heudelotii tended to be present in less salty, slightly more turbid and slightly less warm waters. To our knowledge, no studies on the temperature or turbidity preferences of West African Ariidae have been published to date. Studies of other Ariidae species in various tropical estuarine ecosystems put forward the high eury-thermohaline capacity of these species and their Weberian apparatus acting as an amplifier of sounds and thus facilitating the detection of preys and predators in turbid environments. These particularities allows them to adapt to a large range of environments including turbid or low-salinity waters and to dominate fish assemblages in many tropical estuaries (Barletta and Blaber, 2007; Dantas et al., 2010).

\section{Size structure}

In the estuarine ecosystems studied here, $C$. heudelotii was distinguished from the other two species by a narrower size range and an average length of only $19 \mathrm{~cm}$ (FL). This species rarely exceeded $40 \mathrm{~cm}$ (FL), and its maximum size recorded was $45 \mathrm{~cm}$ (53 cm TL), whereas according to Daget (1992) it can reach $76 \mathrm{~cm}$ (TL). C. latiscutatus and C. parkii reached 
larger sizes, with average lengths of 30 and $27 \mathrm{~cm}$ and maximum lengths of 61 and $53 \mathrm{~cm}$ (73 and $60 \mathrm{~cm} \mathrm{TL}$ ), respectively, compared to 70 and $75 \mathrm{~cm}$ (TL) according to Daget (1992). In a comparative study of the reproductive traits of C. latiscutatus inside and outside the Bamboung MPA (Diop et al., 2017), males averaged $390 \mathrm{~mm}$ (TL) inside the MPA and $380 \mathrm{~mm}$ (TL) outside, with maximum sizes of 609 and $525 \mathrm{~mm}$ (TL), while females averaged $424 \mathrm{~mm}$ (TL) inside the MPA and $402 \mathrm{~mm}$ (TL) outside, with maximum sizes of 750 and $674 \mathrm{~mm}$ (TL). Maximum sizes of $850 \mathrm{~mm}, 730 \mathrm{~mm}$ and $530 \mathrm{~mm}$ (TL) for C. latiscutatus, C. heudelotii and $C$. parkii respectively were measured at sea on the Guinean continental shelf (Conand et al., 1995; Sidibé, 2003). In C. parkii, the maximum size in the estuary therefore seems to be slightly higher than at sea (60 cm vs. $53 \mathrm{~cm}$ TL).

\section{Length-weight relationships and condition factor}

The present study made it possible to propose length-weight relationships for each of the three species studied, based on large numbers of individuals, except for $C$. heudelotii. A global relationship for the three species was also calculated for the purpose of biomass estimates from fishing data where the three species are often grouped together. The allometry coefficient b was always higher than the theoretical value of 3 , indicating a faster increase in weight than in size and thus a favourable environment for these species.

For $C$. latiscutatus, the parameters of the length-weight relationship we propose $\left(\mathrm{K}=0.417^{*} 10^{-}\right.$ ${ }^{5}$ and $\left.\mathrm{b}=3.194\right)$ can be compared to several other parameters for West Africa. The datasets used by Ecoutin and Albaret (2003) $\left(\mathrm{K}=1.32 * 10^{-5}\right.$ and $\mathrm{b}=2.994 ; \mathrm{n}=80$; FL range: 107$523 \mathrm{~mm})$, and by Ecoutin et al. (2005a) $\left(\mathrm{K}=0.486 * 10^{-5}\right.$ and $\mathrm{b}=3.166$; $\mathrm{n}=183$; FL range: 87 $347 \mathrm{~mm}$ ) are included in the present study, but subsequent sampling in the Bamboung and Urok Islands MPAs brought the number of individuals measured to 1,201 and extended the size range (maximum length of $614 \mathrm{~mm}$ ). In a recent study in the Sine Saloum estuary, 
Ndiaye et al. (2015) found $a=0.025$ and $b=2.54(n=130$; TL range: $20-28 \mathrm{~cm})$ and in the PNBA (Mauritania), Correia et al. (2020) estimated $a=0.0026$ and $b=3.31$ for male and female combined ( $\mathrm{n}=346$; TL range: $24.9-85.5 \mathrm{~cm}$ ). These results cannot be directly compared with ours as they both concerned total lengths and Ndiaye et al. (2015) covered a very small size range. Finally, on the Guinean continental shelf, Sidibé (2003) obtained coefficients $a=0.0117$ (i.e., $\left.K=1.027 * 10^{-5}\right)$ and $b=3.033(n=1,789$; FL range $=12-50 \mathrm{~cm})$. With the exception of the results of Ndiaye et al. (2015) and Correia et al. (2020), the different length-weight relationships proposed for C. latiscutatus, whether in estuaries or at sea, produced very similar results. Thus, the weight of a $300 \mathrm{~mm}$ individual (average fork length in our study) was estimated at $340 \mathrm{~g}$ based on the present study, $344 \mathrm{~g}$ according to Ecoutin et al. (2003), 338 g according to Ecoutin et al. (2005a) and 335 g according to Sidibé (2003).

Very few studies propose length-weight relationships for the other two species studied here: C. parkii $\left(\mathrm{K}=0.627 * 10^{-5}\right.$ and $\left.\mathrm{b}=3.137\right)$ and C. heudelotii $\left(\mathrm{K}=0.714 * 10^{-5}\right.$ and $\left.\mathrm{b}=3.111\right)$. A relationship ( $\mathrm{K}=0.506 * 10^{-5}$ and $\mathrm{b}=3.168$; $\mathrm{n}=35$; FL range=72-285 mm) was published for the first time for C. parkii by Ecoutin et al. (2005a) in the Gambia estuary. These parameters were close to those obtained here in a larger sample (591 individuals). For a $300 \mathrm{~mm}$ individual, the weight was estimated at $356 \mathrm{~g}$ and $370 \mathrm{~g}$, respectively, by the two relationships. In the PNBA (Mauritania), Correia et al. (2020) proposed $a=0.0064$ and $b=3.09$ for C. parkii ( $\mathrm{n}=345$ - TL range $24.7-66 \mathrm{~cm})$.

For C. heudelotii, a relationship ( $\mathrm{a}=0.023$ and $\mathrm{b}=2.65$; $\mathrm{n}=104$; TL range: $18.5-26 \mathrm{~cm}$ ) was proposed by Ndiaye et al. (2015), but again in a very narrow size range. Parameters (a=0.025 and $b=2.671 ; n=193$ ) estimated for the Cross River Estuary, Nigeria (Etim, 2000) are available in Fishbase (Froese and Pauly, 2020). However, it is difficult to compare these results with ours, as the type of length and the size range were not given. For a $20 \mathrm{~cm}$ 
individual, the latter relationship (Etim, 2000) estimates the weight at $74 \mathrm{~g}$, while ours estimates it at $103 \mathrm{~g}$.

\section{Reproduction}

In the present study, $13 \%$ of males and $32 \%$ of females, all species combined, had begun sexual maturation. Of the females, only $7 \%$ had reached maturity, $1 \%$ was in the spawning phase and $5 \%$ were at spent stage. This very low percentage of mature individuals is consistent with their classification as Marine-Estuarine species (abundant in estuaries, but do not breed there) by Albaret (1999) and with their classification as marine migrants (C. latiscutatus and C. parkii) and marine straggler (C. heudelotii) by Whitfield (2005). According to Diouf (1996), however, C. parkii can reproduce in estuaries, particularly in the cold dry season, whereas C. latiscutatus and C. heudelotii begin their sexual maturation in estuaries in the hot and dry season.

For C. heudelotii, the beginning of sexual maturity was recorded here in females measuring more than $28 \mathrm{~cm}$ (FL). The sex ratio for this species was fairly close to equilibrium, although it was calculated based on a small number of individuals because the proportion of undifferentiated individuals was almost 50\%, consistent with the low average size $(19 \mathrm{~cm})$. For C. latiscutatus and C. parkii, the smallest mature individuals measured $22.5 \mathrm{~cm}$ and $19 \mathrm{~cm}$ respectively. In C. latiscutatus, females were in the majority overall, as pointed out by Diop et al. (2017): 70\% females and 30\% males inside and outside the Bamboung MPA. However, this bias was less marked in C. latiscutatus individuals under $24 \mathrm{~cm}$ in length, and in C. parkii individuals under $21 \mathrm{~cm}$ in length. This result should be linked to these of Sidibé (2003) for C. latiscutatus on the Guinean continental shelf, where the sex ratio was balanced up to $34 \mathrm{~cm}$, and then increased in favour of females. 
In females of C. latiscutatus, size at first maturity (FL50) was estimated to be $28 \mathrm{~cm}(33 \mathrm{~cm}$ in TL) in Senegal and The Gambia. Diop et al. (2017) reported higher values of TL50 in the Sine Saloum estuary: $40 \mathrm{~cm}$ in the Bamboung MPA and $42 \mathrm{~cm}$ outside. A FL50 of $40 \mathrm{~cm}$ was also proposed by Correia et al. (2020) for C. latiscutatus in the PNBA. However, our results are comparable to those of Sidibé (2003) and Domain et al. (1999), who reported a FL50 of $27.5 \mathrm{~cm}$ and $30 \mathrm{~cm}$ respectively for C. latiscutatus on the Guinean continental shelf.

Our records indicated an average fecundity of $16.2 \pm 2.8$ eggs per female for C. latiscutatus, which is less than the results of Diop et al. (2017), who reported $29 \pm 14$ eggs for this species in the Bamboung MPA and $22 \pm 10$ outside, and than those of Correia et al. (2020) in the PNBA with $45.3 \pm 20.8$ eggs. In C. parkii, fecundity was $26.2 \pm 9.6$ eggs on average, similar to the results of Correia et al. (2020): $25.9 \pm 6.2$.

In the present study, cases of oral incubation were recorded in a few $C$. latiscutatus and $C$. parkii females. Most, if not all, Ariidae are mouth incubators, a mode of reproduction rarely recorded in other catfish (Vreven and De Vos, 2007). Mouthbrooding catfishes are mainly estuarine or marine (Bruton, 1996). Males are generally reported to carry in their mouth relatively large fertilized eggs (e.g. $16 \mathrm{~mm}$ in diameter for Galeichthys feliceps) and hatched larvae up to 100 mm long (Bruton, 1996; Rimmer, 1985; Rimmer and Merrick, 1982; Tilney and Hecht, 1993). In a study of eggs and larvae mouthbreeding in Genidens genidens from Guaratuba bay (Brazil), Chaves (1994) reported that it was not possible to recognize the sex or degree of maturity of the adults carrying eggs, given the small volume of their gonads.

\section{Feeding behaviour}

In the specimens whose stomach content was investigated (80\% C. latiscutatus and $19 \%$ C. parkii), the diet consisted mainly of crustaceans (crabs and shrimps), fish (including pelagic fish) and mollusks, which confirms the classification of West African coastal Ariidae as 
generalist second-level predators. In the Sine Saloum estuary (Senegal), the diet of the three Ariidae was described by Diouf (1996) as being composed of fish and shrimps, plus crab and zooplankton for C. latiscutatus and $C$. heudelotii. In a feeding behaviour study of ten species of Bamboung MPA (Faye et al., 2012), C. latiscutatus was characterised as a macrocarnivore, the volumetric proportions of its preys indicating that it was feeding half on fish (53\%) and the rest on macro-crustaceans (17\%), benthic invertebrates (15\%) and mollusks (10\%). Finally, in the Ebrié Lagoon (Côte d'Ivoire), the diet of C. latiscutatus consisted of juvenile fish, mollusks, shrimps, and crabs (Albaret, 1994).

The genus Carlarius is characterized by the absence of vomerine tooth plates and by well developed oval shaped accessory tooth plates (Marceniuk \& Menezes, 2007). Palatal teeth for C. latiscutatus are in 2 paired patches (Acero \& Betancur, 2016), which is comparable to other ariid catfishes from Australia, Arius thalassinus and Arius bilineatus, having two groups of three contiguous plates of palatine teeth on each side, meeting in the midline (Blaber et al., 1994). The diet of C. latiscutatus was in fact very similar to the diet of these two Australian species, consisting of mainly fish and decapod Crustacea (crab and penaeid prawns). The palatal teeth of $C$. parkii are in two large patches separated by their own diameter or less, while those of $C$. heudelotii are absent or in one or two small patches very distant from each other (Marceniuk \& Menezes, 2007). The palatal teeth of these two species look like those of Arius sp. 3 in Blaber et al. (2014), a primarily invertebrate feeder (alpheid shrimps, crab, polychaetes and molluscs), eating only a small proportion of fish. In the present study, bivalves were indeed more frequent in C. parkii than in C. latiscutatus but no information has been collected about the diet of $C$. heudelotii.

\section{Conclusion}


The analysis of this large dataset covering various types of estuarine, coastal and lagoon ecosystems in six West African countries has helped to consolidate knowledge on the biology of the three coastal Ariidae C. heudelotii, C. latiscutatus and C. parkii. Their regular presence has been attested in all ecosystems, the most abundant species being C. latiscutatus. It is likely that the abundance of coastal Ariidae, shallow-water demersal species, is favoured by the width of the continental shelf, including in the adjacent estuarine and lagoon ecosystems. Their high tolerance to environmental variations (salinity, temperature, turbidity) enables them to occupy estuarine environments as an extension of their coastal habitat, sometimes extending as far as significant distances from the river mouth. They thus move between the sea and the estuaries regardless of their age, as demonstrated by their wide range of sizes in estuaries, comparable to that in the coastal zone. However, C. latiscutatus and C. parkii undeniably have a stronger estuarine affinity than the more marine $C$. heudelotii. They spend their entire life cycle without distinguishing between the sea and estuaries, with the exception of spawning, which takes place at sea, after which they can quickly return to the estuaries, as shown by the presence of mature and mouthbrooding individuals in estuaries. It is therefore very likely that the same population is present in the sea and in the estuary. One hypothesis that could explain the occupation of estuaries by Ariidae could be of a trophic nature, as estuaries have a great wealth of potential prey, shellfish, crustaceans, or juveniles of other species. Comparative studies on their feeding behaviour at sea and in estuaries could enable this hypothesis to be tested.

\section{Acknowledgements}

The authors wish to thank everyone directly or indirectly involved in surveys, species identification and data collection, especially the fishermen and the crew of the research vessels. Without their help, these data could not have been collected. 


\section{References}

Acero P., A. \& Betancur-R., R. (2016). Siluriformes: Ariidae. In K. E. Carpenter \& N. De Angelis (Eds.), The living marine resources of the Eastern Central Atlantic, Vol. 3 Bony fishes part 1 (Elopiformes to Scorpaeniformes) (pp. 1742-1750). FAO, Rome.

Albaret, J. J. (1994). Les poissons : biologie et peuplements. In J. R. Durand, P. Dufour, D.

Guiral \& S. G. F. Zabi (Eds.). Environnement et ressources aquatiques de Côte d'Ivoire : 2. Les milieux lagunaires (pp. 239-280). ORSTOM, Paris. Retrieved from http://horizon.documentation.ird.fr/exl-doc/pleins_textes/pleins_textes_7/divers2/40693.pdf

Albaret, J. J. (1999). Les peuplements des estuaires et des lagunes. In C. Lévêque \& D. Paugy (Eds.), Les poissons des eaux continentales africaines: diversité, écologie, utilisation pour l'homme (pp. 325-350). IRD, Paris. Retrieved from http://horizon.documentation.ird.fr/exldoc/pleins_textes/divers11-10/010018562.pdf

Albaret, J. J., Simier, M., Darboe, F. S., Ecoutin, J. M., Raffray, J., \& Tito de Morais L. (2004). Fish diversity and distribution in the Gambia Estuary, West Africa, in relation to environmental variables. Aquatic Living Resources, 17, 35-46.

Albaret, J. J., \& Legendre, M. (1985). Biologie et Ecologie des Mugilidae en lagune Ebrié (Côte d'Ivoire). Intérêt potentiel pour l'aquaculture lagunaire. Revue d'Hydrobiologie Tropicale, 18, 281-303. Retrieved from http://horizon.documentation.ird.fr/exldoc/pleins_textes/cahiers/hydrob-trop/24993.pdf 
Albaret, J. J., Simier, M., Darboe, F. S., Ecoutin, J. M., Raffray, J., \& Tito de Morais, L. (2004). Fish diversity and distribution in the Gambia Estuary, West Africa, in relation to environmental variables. Aquatic Living Resources, 17, 35-46. https://doi.org/10.1051/alr:2004001

Ba, K., Thiaw, M., Fall, M., Thiam, N., Meissa, B., Jouffre, D., Thiaw, O. T., \& Gascuel, D. (2018). Long-term fishing impact on the Senegalese coastal demersal resources: diagnosing from stock assessment models. Aquatic Living Resources, 31, 8. https://doi.org/10.1051/alr/2017046

Baran, E. (1995). Dynamique spatio-temporelle des peuplements de poissons estuariens en Guinée : relation avec le milieu abiotique (Thèse de Doctorat en Océanologie biologique, Université de Bretagne Occidentale, Brest). Retrieved from http://horizon.documentation.ird.fr/exl-doc/pleins_textes/pleins_textes_6/TDM/42826.pdf

Barletta, M., \& Blaber, S. J. M. (2007). Comparison of fish assemblages and guilds in tropical habitats of the Embley (Indo-West Pacific) and Caeté (Western Atlantic) estuaries. Bulletin of Marine Science, 80, 647-680.

Blaber, S. J. M., Brewer, D. T., \& Salini J. P. (1994). Diet and dentition in tropical ariid catfishes from Australia. Environmental Biology of Fishes, 40, 159-174. https://doi.org/10.1007/BF00002543

Bruton, M. N. (1996). Alternative life-history strategies of catfishes. Aquatic Living Resources, 9, 35-41. 
Burgess, W. E. (1989). An atlas of freshwater and marine catfishes. A preliminary survey of the Siluriformes. T.F.H. Publications, Neptune City, New Jersey, U.S.A.

Camara, M. L., Mérigot, B., Leprieur, F., Tomasini, J. A., Diallo, I., Diallo, M., \& Jouffre, D. (2016). Structure and dynamics of demersal fish assemblages over three decades (1985-2012) of increasing fishing pressure in Guinea. African Journal of Marine Science, 38, 189-206.

Castro, K., Jallow, A., \& Cessay, S. (2013). Description and analysis of The Gambia catfish stock assessment - $\quad 2013 . \quad$ pp. 1-10. $\quad$ Retrieved from https://www.crc.uri.edu/download/GambiaCatfish_stock_assessment508.pdf

Caverivière, A. (1982). Les espèces démersales du plateau continental ivoirien : biologie et exploitation. (Thèse, Université d'Aix-Marseille 2 : Marseille). Retrieved from http://horizon.documentation.ird.fr/exl-doc/pleins_textes/pleins_textes_7/TDM_7/41330.pdf

Caverivière, A. (1993). Les peuplements ichtyologiques démersaux : écologie et biologie. In P. Le Loeuf, E. Marchal \& J. B. Amon Kothias (Eds.). Environnement et ressources aquatiques de Côte d'Ivoire : 1. Le milieu marin (pp. 271-320). ORSTOM, Paris. Retrieved from http://horizon.documentation.ird.fr/exldoc/pleins_textes/pleins_textes_7/divers2/37717.pdf

Caverivière, A., Thiam, M., \& Sylla, A. (1988). Rapport de la troisième campagne de chalutage stratifié sur le plateau continental sénégalais (10-200 M) N/O Louis Sauger (14 octobre au 31 octobre 1988). CRODT, Dakar : Archive CRODT 166. 
Caverivière, A., \& Thiam, M. (1993). Tailles moyennes et taux d'exploitation approchés des principales espèces de poissons débarquées par les chalutiers glaciers entre 1973 et 1989 . In M. Barry-Gérard, T. Diouf \& A. Fonteneau (Eds.). L'évaluation des ressources exploitables par la pêche artisanale sénégalaise : documents scientifiques présentés lors du symposium (pp. 365-384). ORSTOM, Paris. Symposium sur L'Evaluation des Ressources Exploitables par la Pêche Artisanale Sénégalaise, 1993/02/8-13, Dakar. Retrieved from http://horizon.documentation.ird.fr/exl-

doc/pleins_textes/pleins_textes_6/colloques2/41143.pdf

Chaves, P. T. C. (1994). A incubação de ovos e larvas em Genidens genidens (Valenciennes) (Siluriformes, Ariidae) da Baia de Guaratuba, Parana, Brasil. Revista Brasileira de Zoologia. 11, 641-648. https://doi.org/10.1590/S0101-81751994000400008

CIESM (2002). CIESM Atlas of Exotic Fishes in the Mediterranean Sea. Available at: http://www.ciesm.org/atlas/appendix1.html

Chong, V. C., Lee, P. K. Y., \& Lau, C. M. (2010). Diversity, extinction risk and conservation of Malaysian fishes. Journal of Fish Biology, 76, 2009-2066. https://doi.org/10.1111/j.10958649.2010.02685.x

Coates, D. (1991). Biology of fork-tailed catfishes from the Sepik River, Papua New Guinea. Environmental Biology of Fishes, 31, 55-74. 
Conand, F., Camara, S. B., \& Domain, F. (1995). Age and growth of three species of Ariidae (Siluriformes) in coastal waters of Guinea. Bulletin of Marine Science, 56, 58-67.

Correia, E., Carneiro, C., \& Araújo, A. (2020). Reproductive ecology and growth of marine catfishes (Ariidae) supporting sustainable fisheries in Banc d'Arguin National Park, $\begin{array}{lllll}\text { Mauritania. } & \text { Marine } & \text { Biology } & \text { Research, }\end{array}$ https://doi.org/10.1080/17451000.2020.1855658

Cross, H. (2015). Elasmobranch capture by commercial small-scale fisheries in the Bijagos Archipelago, Guinea Bissau. Fisheries Research, 168, 105-108.

Daget, J. (1992). Ariidae. In C. Levêque, D. Paugy \& G. G. Teugels (Eds.). Faune des poissons d'eaux douces et saumâtres de l'Afrique de l'Ouest $=$ The fresh and brackish water fishes of West Africa (pp. 564-568). ORSTOM, Paris.

Daget, J., Gosse J. P., \& Thys van den Audenaerde D. F. E. (1986). Check-list of the freshwater fishes of Africa = Catalogue des poissons d'eau douce d'Afrique : CLOFFA / 2. ORSTOM, Paris.

Dantas, D. V., Barletta, M., Cost, M. F., Barbosa-Cintra, S. C. T., Possatto, F. E., Ramos, J. A. A., Lima, A. R. A., \& Saint-Paul, U. (2010). Movement patterns of catfishes (Ariidae) in a tropical semi-arid estuary. Journal of Fish Biology, 76, 2540-2557. https://doi.org/10.1111/j.1095-8649.2010.02646.x 
Diadhiou, H. D., Sadio, O., Diallo, S., \& Agboba, C. (2018). Contribution to a better knowledge of bycatch of fixed gillnets of shrimps (Farfantepenaeus notialis) in the Casamance estuary in Southern Senegal. International Journal of Agricultural Policy and Research, 6, 189-200.

Diop, K., Diouf, K., Diolne, M. D., Diadhiou, H. D., Thiaw, M., Ndiaye, P., \& Jouffre, D. (2017). Study comparing the reproductive traits of the catfish, Arius latiscutatus (Günther, 1864) inside and outside the Bamboung marine protected area, Saloum Delta, Senegal. International Journal of Fisheries and Aquatic Studies, 5, 91-99.

Diouf, P. S. (1996). Les peuplements de poissons des milieux estuariens de l'Afrique de l'Ouest : l'exemple de l'estuaire hyperhalin du Sine-Saloum. (Thèse de Biologie des Populations et Ecologie, Université de Montpellier 2, Montpellier). Retrieved from: http://horizon.documentation.ird.fr/exldoc/pleins_textes/pleins_textes_7/TDM_7/010008130.pdf

Domain, F. (1977). Carte sédimentologique du plateau continental sénégambien : extension à une partie du plateau continental de la Mauritanie et de la Guinée Bissau. ORSTOM, Paris. Retrieved $\quad$ from: http://horizon.documentation.ird.fr/exldoc/pleins_textes/pleins_textes_5/notexp/08891.pdf

Domain, F. (1980). Contribution à la connaissance de l'écologie des poissons démersaux du plateau continental sénégalo-mauritanien : les ressources démersales dans le contexte général du golfe de Guinée. (Thèse de Science Naturelle, Université de Paris 6, Paris). 
doc/pleins_textes/pleins_textes_6/divers1/00307.pdf

Domain, F., Richer de Forges, B. (1985). Carte sédimentologique du plateau continental mauritanien (entre le cap Blanc et $17^{\circ} \mathrm{N}$ ) à 1 : 200000 : feuilles Nouadhibou et Nouakchott. ORSTOM, Paris. Retrieved from: http://horizon.documentation.ird.fr/exldoc/pleins_textes/pleins_textes_5/notexp/31641.pdf

Domain, F., Keita, M. \& Morize, E. (1999). Typologie générale des ressources démersales du plateau continental. In F. Domain, P. Chavance \& A. Diallo (Eds.). La pêche côtière en Guinée : ressources et exploitation (pp. 53-85). CNSHB/IRD, Paris.

Ecoutin, J. M. \& Albaret, J. J. (2003). Relation longueur-poids pour 52 espèces de poissons des estuaires et lagunes de l'Afrique de l'Ouest. Cybium, 27, 3-9.

Ecoutin, J. M., Albaret, J. J. \& Trape, S. (2005a). Length-weight relationships for fish populations of a relatively undisturbed tropical estuary: the Gambia. Fisheries Research, 72, 347-351. https://doi.org/10.1016/j.fishres.2004.10.007

Ecoutin, J. M., Richard, E., Simier, M. \& Albaret, J. J. (2005b). Spatial versus temporal patterns in fish assemblages of a tropical estuarine coastal lake: The Ebrié Lagoon (Ivory Coast). Estuarine, Coastal and Shelf Science, 64, 623-635. 
Ecoutin, J. M., Simier, M., Albaret, J. J., Laë, R., \& Tito de Morais, L. (2010). Changes over a decade in fish assemblages exposed to both environmental and fishing constraints in the Sine Saloum estuary (Senegal). Estuarine, Coastal and Shelf Science, 87, 284-292.

Ecoutin, J. M., Simier, M., Albaret, J.J., Laë, R., Raffray, J., Sadio, O., \& Tito de Morais, L. (2014). Ecological field experiment of short-term effects of fishing ban on fish assemblages in

a tropical estuarine MPA. Ocean \& Coastal Management, 100, 74-85. https://doi.org/10.1016/j.ocecoaman.2014.08.009

Etim, L. (2000). Length-weight relationship of eight fish species from the Cross River, Nigeria. Global Journal of Pure and Applied Science, 6, 571-575.

Faye, D., Le Loc'h, F., Thiaw, O. T., \& Tito de Morais, L. (2012). Mechanisms of food partitioning and ecomorphological correlates in ten fish species from a tropical estuarine marine protected area (Bamboung, Senegal, West Africa). African Journal of Agricultural Research, 7, 443-455.

Fontana, A. (1981). Milieu marin et ressources halieutiques de la République Populaire du Congo. ORSTOM, Paris. Retrieved from http://horizon.documentation.ird.fr/exldoc/pleins_textes/pleins_textes_5/pt5/travaux_d/01218.pdf

Fowler, H. W. (1936). The marine fishes of West Africa. Bulletin of the American Museum of Natural History, 1, 329-334. 
Fricke, R., Eschmeyer, W. N., \& Van der Laan, R. (Eds.) (2020). Eschemeyer's catalog of fishes: Genera, $\quad$ species, $\quad$ Available at http://researcharchive.calacademy.org/research/ichthyology/catalog/fishcatmain.asp.

Froese, R., \& Pauly, D. (2020). FishBase. World Wide Web electronic publication. Available at http://www.fishbase.org.

Froese, R. (2006). Cube law, condition factor and weight-length relationships: history, metaanalysis and recommendations. Journal of Applied Ichthyology, 22, 241-253. https://doi.org/10.1111/j.1439-0426.2006.00805.x

Gascuel, D., Monteiro, C., Yahya, S., Brahim, K., Ould Bouzouma, M. M., et al. (2006). Estimation des captures par espèce, pour les différentes flottilles opérant en Mauritanie de 1991 à 2005. 6. Groupe de travail de l'IMROP, Dec 2006, Nouadhibou, Mauritanie. Retrieved from https://hal-agrocampus-ouest.archives-ouvertes.fr/hal-00729501

Golani, D., \& Ben-Tuvia, A. (1986). New records of fishes from the Mediterranean coast of Israel including Red Sea immigrants. Cybium, 10, 285-291.

Golani, D., \& Sonin, O. (1996). The occurrence of the tropical West African marine fishes Acanthurus monroviae (Acanthuridae) and Arius parkii (Ariidae) in the Levant. Aquatic Journal of Ichthyology and Aquatic Biology, 2, 1-3. 
Kaimuddin, A. H., Laë, R., \& Tito de Morais, L. (2016). Fish species in a changing world: the route and timing of species migration between tropical and temperate ecosystems in Eastern Atlantic. Frontiers in Marine Science, 3, 162. https://doi.org/10.3389/fmars.2016.00162

Kantoussan, J., Ecoutin, J. M., Simier, M., Tito de Morais, L., \& Laë, R. (2012). Effects of salinity on fish assemblage structure: An evaluation based on taxonomic and functional approaches in the Casamance estuary (Senegal, West Africa). Estuarine, Coastal and Shelf Science, 113, 152-162.

Koivogui, P., Konan, Y.A., Coulibaly, B., Kouamelan, E.P., \& Koné, T. (2020). Reproductive biology of marine catfish, Arius latiscutatus (Günther, 1864) and Arius gigas (Boulenger, 1911) from the Bays of Guinea. Annual Research \& Review in Biology. 35, 1-13. https://doi.org/10.9734/arrb/2020/v35i830254

Laë, R., Ecoutin J. M., Mendy A., Raffray J., Weigel J. Y., Sadio O., \& Djobe O. (2004). Effects of a targeted shrimp (Penaeus notialis) exploitation on fish catches in the Gambia estuary. Aquatic Living Resources, 17, 75-85. https://doi.org/10.1051/alr:2004010

Lima, A. R. A., Barletta, M., Dantas, D. V., Ramos, J. A. A., Costa, M. F. (2013). Early development of marine catfishes (Ariidae): from mouth brooding to the release of juveniles in nursery habitats. Journal of Fish Biology. 82:1990-2014. https://doi.org/10.1111/jfb.12128

Longhurst, A. R. (1969). Species assemblages in tropical demersal fisheries, Proceedings of the Symposium on the Oceanography and Fisheries Resources of the Tropical Atlantic, Abidjan, Côte d’Ivoire, 20-28 October 1966 (pp. 147 -170). Unesco, Paris. 
Marceniuk, A. P. (2003). Relações filogenéticas e revisão dos gêneros da família Ariidae (Ostariophysi, Siluriformes). (PhD. Thesis, University of São Paulo, Brasil).

Marceniuk, A. P., \& Menezes, N. A. (2007). Systematics of the family Ariidae (Ostariophysi, Siluriformes), with a redefinition of the Genera. Zootaxa, 1416, 1-126.

Martin, L. (1973). Carte sédimentologique du plateau continental de Côte d'Ivoire. ORSTOM, Paris. Retrieved from: http://horizon.documentation.ird.fr/exldoc/pleins_textes/pleins_textes_5/notexp/06021.pdf

Ndiaye, W., Sarr, A., Diouf, M., Faye, A., \& Mbodji, A. (2015). Length-weight relationships of some fish species from the Bandiala River in Saloum Delta, Senegal. International Journal of Advanced Research, 3, 132-138.

Ndour, I., Thiam, N., Fall, M., \& Diadhiou, H. D. (2016). Temporal dynamics of demersal fishing profiles of the artisanal fishing fleet segment on the Petite Côte of Senegal. International Journal of Advanced Research, 4, 1408-1419.

Panfili, J., Thior, D., Ecoutin, J. M., Ndiaye, P., \& Albaret, J. J. (2006). Influence of salinity on the size at maturity for fish species reproducing in contrasting West African estuaries. Journal of Fish Biology, 69, 95-113. https://doi.org/10.1111/j.1095-8649.2006.01069.x

Paugy, D., \& Lévêque, C. (1999). L'échantillonnage des peuplements de poissons. In C. Lévêque \& D. Paugy (Eds.), Les poissons des eaux continentales africaines : diversité, 
écologie, utilisation par l'homme (pp. 227-236). IRD, Paris. Retrieved from http://horizon.documentation.ird.fr/exl-doc/pleins_textes/divers11-10/010018555.pdf

R Core Team (2020). R: A language and environment for statistical computing. R Foundation for Statistical Computing, Vienna, Austria. Available at https://www.R-project.org/

Rimmer, M. A. (1985). Early development and buccal incubation in the fork-tailed catfish Arius graeffei Kner \& Steindachner (Pisces: Ariidae) from the Clarence river, New South Wales. Marine and Freshwater Research. 36, 405-411. https://doi.org/10.1071/MF9850405

Rimmer, M. A. \& Merrick, J. R. (1983). A review of reproduction and development in the fork-tailed catfishes (Ariidae). Proceedings of the Linnean Society of New South Wales, 107, $41-50$.

Sadio, O. (2015). Efficacité des Aires Marines Protégées comme outil de restauration des ressources marines et de gestion des stocks halieutiques : l'expérience ouest africaine. (Thèse de doctorat en Ecologie Halieutique, Université de Bretagne Occidentale, Brest, France). Retrieved from http://horizon.documentation.ird.fr/exl-doc/pleins_textes/divers1702/010068993.pdf

Sadio, O., Simier, M., Ecoutin, J. M., Raffray, J., Laë, R., \& Tito de Morais L. (2015). Effect of a marine protected area on tropical estuarine fish assemblages: Comparison between protected and unprotected sites in Senegal. Ocean \& Coastal Management, 116, 257-269. https://doi.org/10.1016/j.ocecoaman.2015.08.004 
Sidibé, A. (2003). Les ressources halieutiques démersales côtières de la Guinée : exploitation, biologie et dynamique des principales espèces de la communauté à Sciaenidés. (Thèse de doctorat spécialité Halieutique, ENSAR, Rennes). Retrieved from http://horizon.documentation.ird.fr/exl-doc/pleins_textes/divers17-10/010043889.pdf

Simier, M., Blanc, L., Aliaume, C., Diouf, P. S., \& Albaret, J. J. (2004). Spatial and temporal structure of fish assemblages in an "inverse estuary", the Sine Saloum system (Senegal). Estuarine, Coastal and Shelf Science, 59, 69-86.

Simier, M., Ecoutin, J. M., \& Tito de Morais, L. (2019). The PPEAO experimental fishing dataset: Fish from West African estuaries, lagoons and reservoirs. Biodiversity Data Journal, 7:e31374, https://doi.org/10.3897/BDJ.7.e31374

Taylor, W. R. (1986). Family No. 59: Ariidae. In M. M. Smith, \& P. C. Heemstra (Eds.). Smiths' Sea Fishes (pp. 211-213). Macmillan, Johannesburg.

Taylor, W. R. (1990). Ariidae. In J. C. Quéro, J. C. Hureau, C. Karrer, A. Post, \& L. Saldanha (Eds.), Check-list of the fishes of the eastern tropical Atlantic, vol. 3. (pp. 230-234). Unesco, Paris.

Tilney, R. L. \& Hecht, T. (1993). Early ontogeny of Galeichthys feliceps from the south east coast of South Africa. Journal of Fish Biology. 43, 183-212. https://doi.org/10.1111/j.10958649.1993.tb00422.x 
Vreven, E. J., \& De Vos, L. (2007) 18. Ariidae = 18. Ariidae. In M. L. J. Stiassny, G. G. Teugels, C. D. Hopkins \& D. Paugy (Eds.). Poissons d'eaux douces et saumâtres de basse Guinée, ouest de l'Afrique centrale: volume 1 = The fresh and brackish water fishes of lower Guinea, west-central Africa: volume 1 (pp. 573-578). IRD, MNHN, MRAC, Paris, Tervuren.

Whitfield, A. K. (2005). Preliminary documentation and assessment of fish diversity in subSaharan African estuaries. African Journal of Marine Science, 27, 307-324.

Yañez-Arancibia, A., \& Lara-Dominguez, A. (1988). Ecology of three catfishes (Ariidae) in a tropical coastal ecosystem - Southern Gulf of Mexico. Marine Ecology - Progress Series, 49, 215-230. 


\section{List of tables}

Table 1. Sampling effort (Number of fishing operations) and distribution of the three Ariidae species in the ecosystems studied: number of fishing operations where the species occurred (Occ); Abundance (Numbers); Biomass in kg (Weight).

Table 2. Numbers after extrapolation, minimum and maximum length and mean length \pm standard deviation per species.

Table 3. Maximum length in mm and total number of individuals measured (in brackets) per species and country.

Table 4. Length-weight relationships in all ecosystems combined for the three Ariidae species pooled and per species. Numbers, allometry coefficient b ( \pm standard deviation), condition coefficient $\mathrm{K}$, correlation coefficient $\mathrm{r}$, length and weight range.

Table 5. Distribution per sex and species of the number of individuals subjected to sex determination.

$\underline{\text { Table } 6}$. Fork length in mm of the smallest individual beginning its sexual maturation (stage $\geq$ 3) and number of mature individuals measured (in brackets), per country, species, and sex.

Table 7. Distribution of the number of individuals whose stomach content was investigated, per country and species. 


\section{Figure captions}

Figure 1. Map of West Africa with the countries and ecosystems studied.

Figure 2. Distribution of occurrences of the 3 West African coastal Ariidae species according to surface salinity (A), temperature in ${ }^{\circ} \mathrm{C}(\mathrm{B})$, bottom depth in $\mathrm{m}(\mathrm{C})$ and water transparency in $m(D)$.

Figure 3. Size frequency distribution (per $20 \mathrm{~mm}$ class) of C. heudelotii (A), C. latiscutatus (B) and C.parkii (C).

Table 1. Sampling effort (Number of fishing operations) and distribution of the three Ariidae species in the ecosystems studied: number of fishing operations where the species occurred (Occ); Abundance (Numbers); Biomass in kg (Weight).

\begin{tabular}{|c|c|c|c|c|c|c|c|c|c|c|c|}
\hline \multirow[t]{5}{*}{ Country } & \multirow[t]{5}{*}{ Ecosystem } & Numb & \multicolumn{3}{|c|}{ C. heudelotii } & \multicolumn{3}{|c|}{ C. latiscutatus } & \multicolumn{3}{|c|}{ C. parkii } \\
\hline & & er of & $\mathrm{O}$ & Num & Wei & $\mathrm{Oc}$ & Numb & Weig & $\mathrm{O}$ & Num & $\mathrm{We}$ \\
\hline & & fishing & $\mathrm{cc}$ & bers & ght & $\mathrm{c}$ & ers & ht & $\mathrm{cc}$ & bers & ight \\
\hline & & operat & & & & & & & & & \\
\hline & & ions & & & & & & & & & \\
\hline Maurita & Banc & 79 & 6 & 73 & 9.14 & 2 & 2 & 8.70 & 18 & 246 & 58. \\
\hline \multirow[t]{3}{*}{ nia } & d'Arguin & & & & & & & & & & 36 \\
\hline & National & & & & & & & & & & \\
\hline & Park & & & & & & & & & & \\
\hline \multirow[t]{3}{*}{ Senegal } & Sine & 479 & 6 & 9 & 1.88 & 47 & 157 & 46.7 & 32 & 94 & 23. \\
\hline & Saloum & & & & & & & 7 & & & 70 \\
\hline & estuary & & & & & & & & & & \\
\hline
\end{tabular}




\begin{tabular}{|c|c|c|c|c|c|c|c|c|c|c|c|}
\hline & Bamboung & 426 & 3 & 3 & 2.41 & 11 & 2,124 & 1,11 & 69 & 842 & 387 \\
\hline & MPA & & & & & 1 & & 9.77 & & & .50 \\
\hline The & Gambia & 215 & 16 & 56 & 10.1 & 77 & 496 & 64.4 & 37 & 115 & 10. \\
\hline \multirow[t]{2}{*}{ Gambia } & River & & & & 6 & & & 5 & & & 56 \\
\hline & estuary & & & & & & & & & & \\
\hline Guinea- & Urok & 33 & 0 & 0 & 0 & 31 & 221 & 86.6 & 15 & 73 & 23. \\
\hline \multirow[t]{2}{*}{ Bissau } & Islands & & & & & & & 6 & & & 43 \\
\hline & MPA & & & & & & & & & & \\
\hline \multirow[t]{4}{*}{ Guinea } & Fatala & 109 & 7 & 21 & 1.91 & 21 & 46 & 5.22 & 2 & 9 & 0.3 \\
\hline & estuary & & & & & & & & & & 9 \\
\hline & Dangara & 46 & 7 & 136 & 9.78 & 9 & 23 & 3.86 & 5 & 6 & 1.7 \\
\hline & Inlet & & & & & & & & & & 8 \\
\hline Côte & Ebrié & 397 & 0 & 0 & 0 & 6 & 15 & 1.13 & 0 & 0 & 0 \\
\hline d'Ivoire & Lagoon & & & & & & & & & & \\
\hline
\end{tabular}


Table 2. Numbers after extrapolation, minimum and maximum length and mean length \pm standard deviation per species.

\begin{tabular}{lrrr}
\hline Species & Numbers & Length range (mm) & Mean length (mm) \pm SD \\
\hline C. heudelotii & 279 & $84-453$ & $193.0 \pm 66.9$ \\
C. latiscutatus & 3,136 & $53-614$ & $301.7 \pm 82.8$ \\
C. parkii & 1,401 & $72-525$ & $274.7 \pm 86.5$ \\
\hline
\end{tabular}


Table 3. Maximum length in $\mathrm{mm}$ and total number of individuals measured (in brackets) per species and country.

\begin{tabular}{lcrl}
\hline Country & C. heudelotii & C. latiscutatus & C. parkii \\
\hline Mauritania & $370(73)$ & $305(2)$ & $508(144)$ \\
Senegal & $453(11)$ & $614(888)$ & $525(556)$ \\
The Gambia & $410(57)$ & $366(498)$ & $343(102)$ \\
Guinea-Bissau & - & $557(221)$ & $450(73)$ \\
Guinea & $369(89)$ & $395(57)$ & $423(15)$ \\
\hline
\end{tabular}


Table 4. Length-weight relationships in all ecosystems combined for the three Ariidae species pooled and per species. Numbers, allometry coefficient $b$ ( \pm standard deviation), condition coefficient $\mathrm{K}$, correlation coefficient $\mathrm{r}$, length and weight range.

\begin{tabular}{|c|c|c|c|c|c|c|}
\hline Species & Numbers & $b \pm S D$ & $\begin{array}{r}\text { K }\left(.10^{-}\right. \\
5\end{array}$ & $\mathbf{r}$ & $\begin{array}{r}\text { Length range } \\
(\mathrm{mm})\end{array}$ & $\begin{array}{r}\text { Weight range } \\
\text { (g) }\end{array}$ \\
\hline Ariidae & 1,830 & $\begin{array}{r}3.159 \pm \\
0.009\end{array}$ & 0.524 & 0.99 & $87-614$ & $7-4,100$ \\
\hline C. heudelotii & 21 & $\begin{array}{r}3.111 \pm \\
0.064\end{array}$ & 0.714 & 0.99 & $155-453$ & $49-1,386$ \\
\hline C. latiscutatus & 1,201 & $\begin{array}{r}3.194 \pm \\
0.010\end{array}$ & 0.417 & 0.99 & $87-614$ & $7-4,100$ \\
\hline C. parkii & 591 & $\begin{array}{r}3.137 \pm \\
0.016\end{array}$ & 0.627 & 0.99 & $102-525$ & $12-2,225$ \\
\hline
\end{tabular}


Table 5. Distribution per sex and species of the number of individuals subjected to sex determination.

\begin{tabular}{lrrr}
\hline \multicolumn{1}{c}{ Sex } & C. heudelotii & C. latiscutatus & C. parkii \\
\hline Immature & 73 & 66 & 67 \\
Female & 52 & 824 & 369 \\
Male & 43 & 404 & 242 \\
\hline
\end{tabular}


Table 6. Fork length in mm of the smallest individual beginning its sexual maturation (stage $\geq$ 3) and number of mature individuals measured (in brackets), per country, species, and sex.

\begin{tabular}{lcccccc}
\hline Country & \multicolumn{2}{c}{ C. heudelotii } & \multicolumn{2}{c}{ C. latiscutatus } & \multicolumn{2}{c}{ C. parkii } \\
\cline { 2 - 7 } & Male & Female & Male & Female & Male & Female \\
\cline { 2 - 7 } Mauritania & - & $280(4)$ & - & - & $345(1)$ & $287(9)$ \\
Senegal & - & $312(2)$ & $254(22)$ & $230(184)$ & $239(61)$ & $190(117)$ \\
The Gambia & - & $410(1)$ & - & $225(31)$ & - & $213(5)$ \\
Guinea-Bissau & - & - & - & $290(30)$ & - & $291(8)$ \\
Guinea & $248(2)$ & - & $245(8)$ & $255(4)$ & - & - \\
\hline
\end{tabular}


Table 7. Distribution of the number of individuals whose stomach content was investigated, per country and species.

\begin{tabular}{lccc}
\hline Country & C. heudelotii & C. latiscutatus & C. parkii \\
\hline Mauritania & 0 & 0 & 6 \\
Senegal & 0 & 100 & 33 \\
The Gambia & 2 & 22 & 2 \\
Guinea-Bissau & 0 & 111 & 14 \\
\hline
\end{tabular}




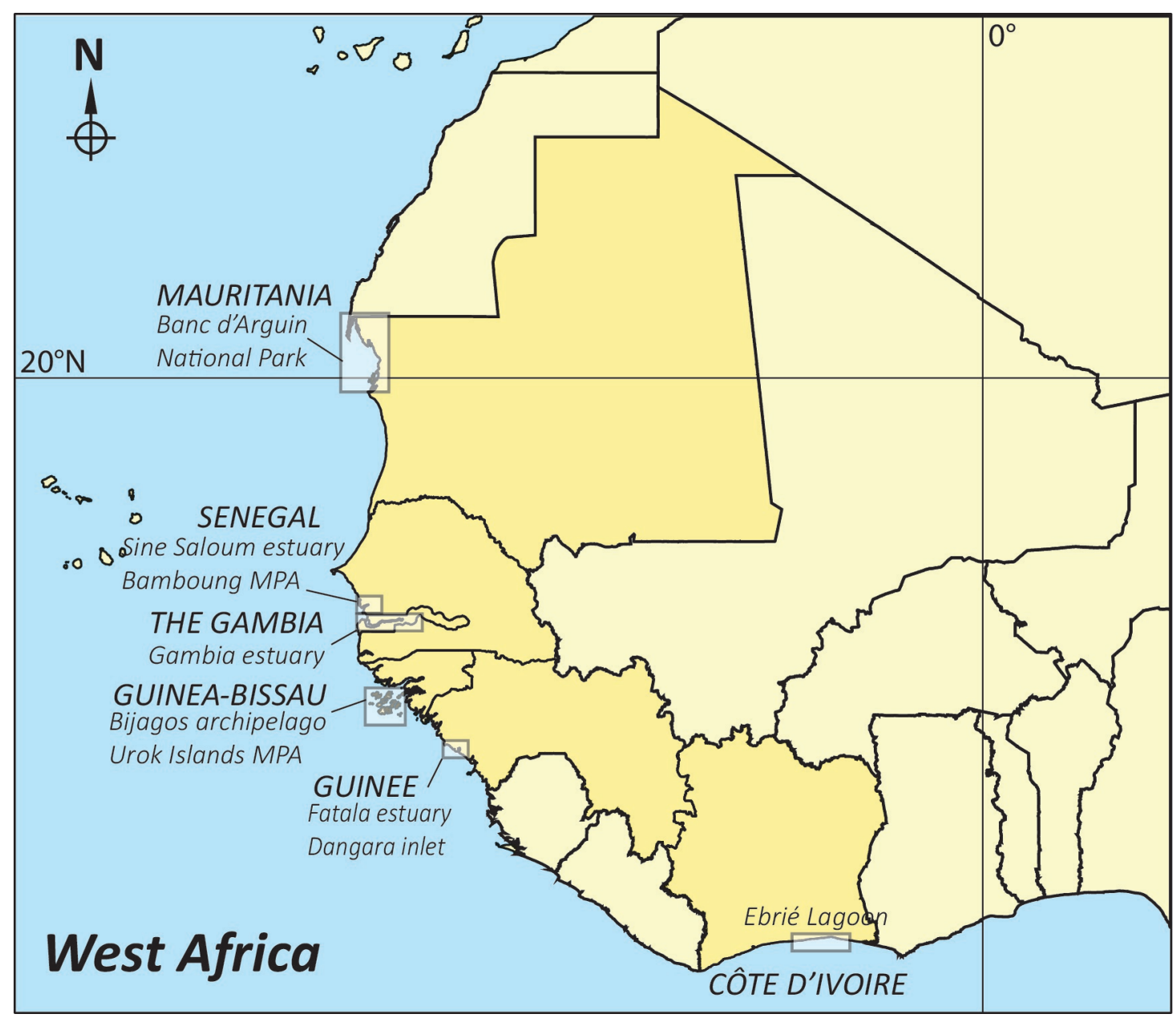

jfb_14751_fig1_jfb-ms-21-0067 - r1.eps 

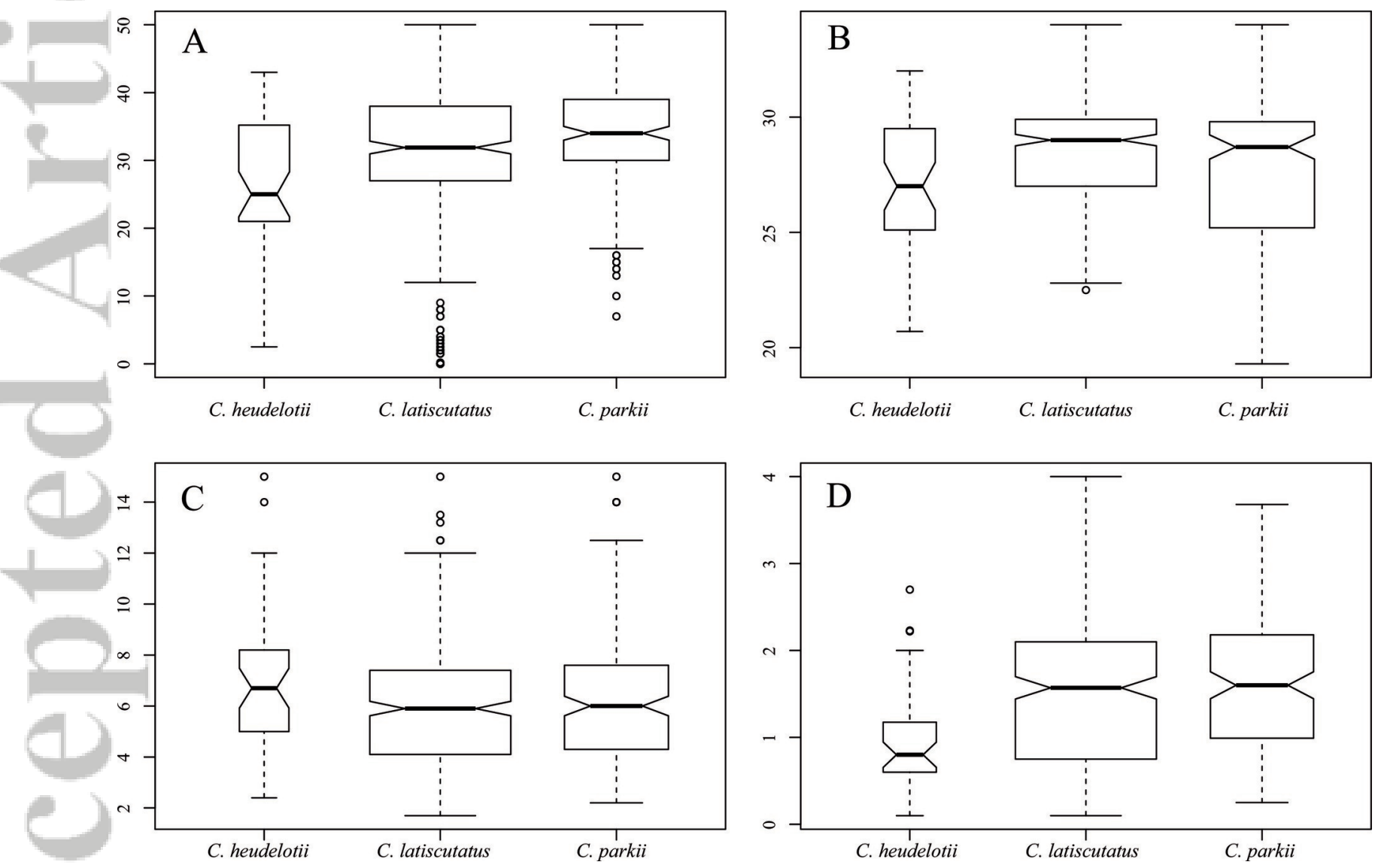

jfb_14751_fig2_jfb-ms-21-0067 - r1.eps 

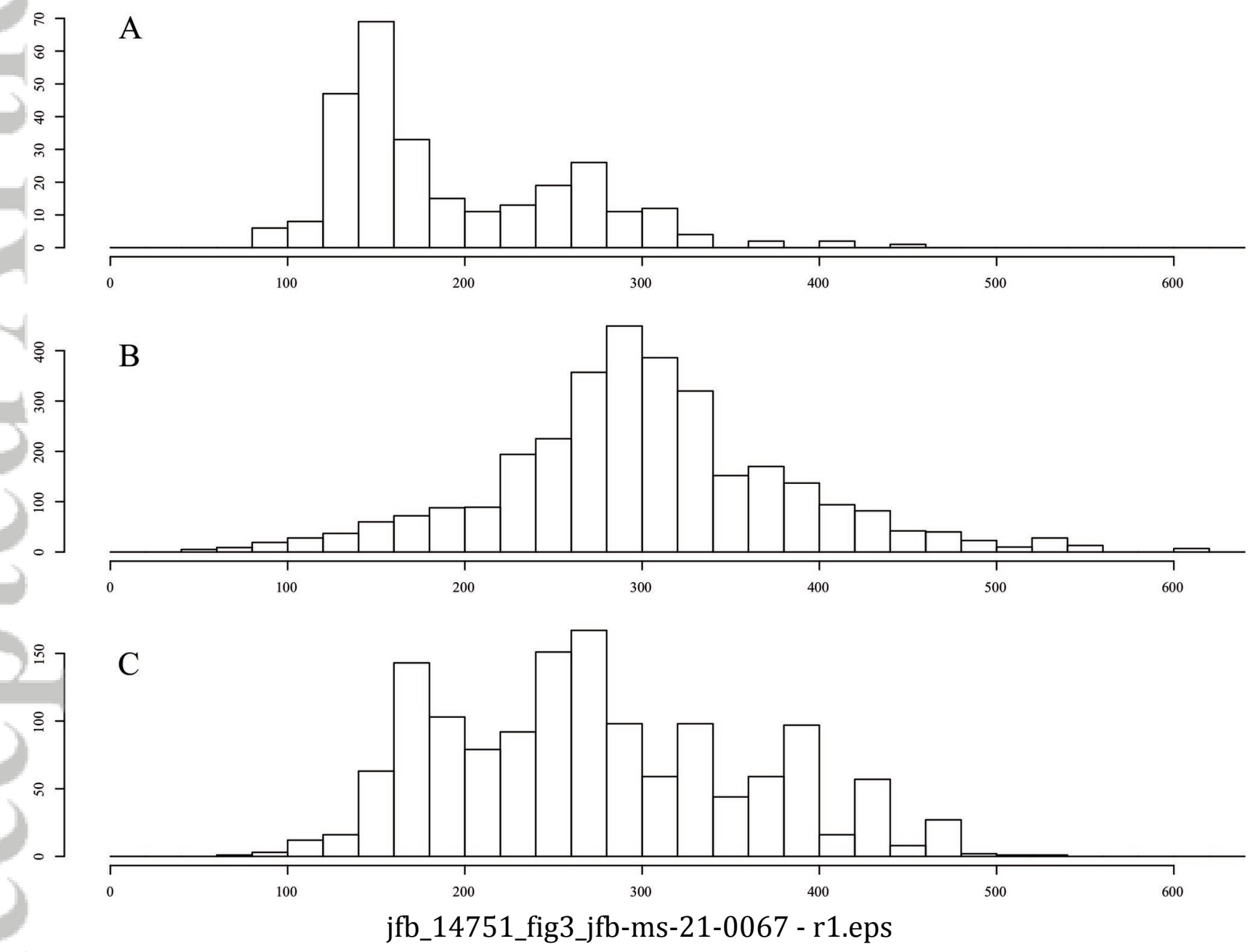


\section{Significance statement}

Three species of sea catfish (Ariidae) are commonly fished on the coasts and estuaries of West Africa. Using a comprehensive dataset collected during experimental fishing surveys, we provide information about their environmental preferences, size structure, reproduction and feeding behaviour. Thanks to their high environmental tolerance, they are able to occupy both the continental shelf and adjacent estuaries throughout the year and throughout their life cycle, with the exception of spawning, which takes place at sea. 